Article

\title{
Improvements of Design for Safety in Construction through Multi-Participants Perception Analysis
}

\author{
Jayho Soh, Jaewook Jeong *(i) and Jaemin Jeong \\ Department of Safety Engineering, Seoul National University of Science and Technology, 232 Gongneung-ro, \\ Nowon-gu, Seoul 01811, Korea; 14111334@seoultech.ac.kr (J.S.); ss96011@seoultech.ac.kr (J.J.) \\ * Correspondence: jaewook.jeong@seoultech.ac.kr; Tel.: +82-2-970-6381
}

Received: 11 June 2020; Accepted: 27 June 2020; Published: 30 June 2020

check for updates

Featured Application: Relative importance of multi-participant perception is discussed in this study to improve safety design efforts in South Korea.

\begin{abstract}
For several decades, the number of reported accidents and fatal incidents in the construction industry has remained high compared to those in other industries. Therefore, many studies have been conducted in an effort to reduce accidents and fatal incidents in the construction industry. Recently, construction safety management has shifted from the construction phase to the pre-construction phase, ultimately to eliminate fatal incidents. In line with this change, South Korea enacted the Design for Safety (DfS) process in 2016. However, the current DfS process remains not well implemented for several reasons. Therefore, this study aims to present eight alternatives to improve the DfS process and suggests DfS improvement priorities by considering construction project participants and career levels using what is known as a fuzzy-analytical hierarchy process (F-AHP) analysis. The results of this study are as follows. First, respondents overall suggested improvements in the area of 'assignment of responsibility for DfS to the client' (0.196). Second, improvement priorities were also identified according to construction project participants and career levels. The results of the study can be utilized as basic information for DfS improvements during construction projects.
\end{abstract}

Keywords: Design for Safety; construction safety; Fuzzy-Analytical Hierarchy Process; Construction project participants

\section{Introduction}

The construction industry recorded high injury and fatal incident rates over the past few decades [1-3]. In the construction industry, according to the '2019 Analysis of Industrial Accident Status' by South Korea's Ministry of Employment and Labor, the number of victims of industrial accidents in 2019 was 25,298, which accounted for $26.9 \%$ of all industrial accident victims during that year. In addition, there were 428 fatalities in the construction industry, accounting for $50.1 \%$ of all deaths from all industrial accidents for that year [4].

Many previous studies have been conducted to reduce and eliminate construction accidents focused on construction safety management in the construction phase. Most of the accidents that occur in the construction phase, however, can actually be predicted and prevented in the design phase $[5,6]$. Given the increased awareness of the need for construction safety management in the design phase, there has been a paradigm shift in construction safety management from the construction phase to the design phase, whereby all construction project participants, such as the clients, designers, contractors, and construction managers, are involved in construction safety management from the design phase [7-9]. 
Design for Safety (DfS) is a system that takes into account the safety of construction workers from the design phase [10]. DfS is designed to discover risk factors in advance from the design phase and thus to perform risk assessments and establish risk mitigation measures. DfS also refers to activities that reflect the risk factors in the design documents to reduce and eliminate risks [11-15]. In a similar manner, as the importance of construction safety management in the design phase has been highlighted, DfS has been introduced worldwide. Examples include Construction Design Management (CDM) in the UK, DfS in Singapore, Prevention through Design (PtD) in the U.S., and Safe Design in Australia [11-14]. These efforts seek to reduce construction accidents by properly implementing each type of DfS $[15,16]$.

In South Korea, the Ministry of Land, Infrastructure, and Transport (MLIT) introduced DfS in 2016, and it is currently in operation [17]. As DfS is still in its infancy in South Korea, however, various problems have arisen during its implementation. For example, in South Korea DfS is applied only to certain public construction projects, and it is supposed to be implemented upon $80 \%$ completion of the construction document preparation phase. Therefore, DfS in South Korea has many limitations owing to the fact that the applicable range of construction projects is relatively narrow compared to those in other countries [18-23].

The DfS process is implemented in the design phase and is carried out in collaboration with multiple participants during its application to the construction phase. During this process, however, participants have different perceptions of DfS problems and the corresponding improvements that are necessary $[6,10,16,21-28]$. Therefore, to enhance the effects of DfS, each participant must increase his awareness of DfS and provide suggestions for improvement priorities [28]. Meanwhile, as the career level in the construction industry becomes higher, the overall understanding of DfS increases. Therefore, the DfS problems and needed improvements as perceived by the participants vary depending on the career level in the construction industry $[6,26,27]$. For this reason, researchers can conduct a comparative analysis of perceptions according to career level. Therefore, the present study aims to draw essential DfS improvement alternatives and suggest factors that should be prioritized through a questionnaire survey and to determine the relative importance levels of certain improvements of DfS in South Korea, with the importance levels perceived by a construction project participant and those at different career levels, then compared using weighting factors, respectively.

\section{Literature Review}

Numerous studies have been carried out to develop DfS. These include (1) studies that analyzed the problems of DfS in South Korea or overseas and suggested improvements for its further development, (2) studies that analyzed problems related to DfS in South Korea or overseas and determined necessary improvements by considering the perceptions of construction project participants, and (3) studies that analyzed problems related to DfS in South Korea or overseas and determined the necessary improvements by considering the perceptions of the several DfS participants in the country.

First, analyses of the problems considering institutional aspects for the development of the DfS system were carried out in several studies [7,15,16,18,29-35]. Particularly in relation to the DfS in South Korea, Ahn (2018) compared legislation pertaining to construction safety management in South Korea and the UK and suggested methods by which to develop South Korea's construction safety management systems [30]. In other countries, Toole and Gambatese (2008) suggested how PtD should develop in the future. In their study, they analyzed the research and suggested a trajectory to improve PtD [15]. Gangolells et al. (2010) proposed a quantitative methodology for evaluating safety performance in PtD. Their methodology was used to compare and evaluate the safety levels in the design phase [31]. Sadeghi et al. (2015) proposed safety indicators to evaluate safety levels among construction workers in the design phase. The safety indicators present the safety levels and provide decision makers with information about safety behaviors [33].

Second, studies sought to analyze problems related to DfS in South Korea or overseas and to deduce its needed improvements by considering the perception levels by construction project 
participant $[6,16,24,25,27]$. The following are some case studies in South Korea. Ahn (2006) argued for a need to change the focus in the safety management of construction works from the contractors to the clients, and emphasized the need for legal responsibilities [24]. The following, on the other hand, are some examples of overseas case studies. Ogunde et al. (2014) conducted a questionnaire survey of 60 companies and clients to assess their compliance with Nigeria's CDM regulations [16]. Hallowell and Hansen (2016) measured how much the designer's risk perceptions can be improved through training and mnemonics. The measurement results showed that the designers' risk perceptions were improved by $27 \%$ on average [6]. Toole et al. (2017) analyzed if the clients know the concept of PtD and how they think about it based on a case study of four client companies. The research results provided 13 key factors for the application of PtD [27].

Third, other studies analyzed the problems related to DfS in South Korea or other countries and deduced the most necessary improvements by considering the perception levels of several DfS participants $[10,19,21,25,28]$. The following are some of the case studies in South Korea. Kim et al. (2019) presented seven problems associated with DfS in South Korea and compared them with those of overseas DfS cases to suggest improvements [19]. Examples of overseas case studies include the following. Langar et al. (2016) conducted a questionnaire survey of 69 companies to investigate knowledge and awareness of $\mathrm{PtD}$ in the construction industry. Their research shows that only $8.7 \%$ of companies knew about PtD [25]. Gambatese et al. (2005) investigated the safety management of construction tasks in the project design process, suggesting a pilot study to determine the practicality of introducing DfS. Their research also assessed the applicability of DfS considering certain factors, and related impacts, by interviewing 19 designers and 32 contractors [10]. Tymvios and Gambatese (2016) conducted a survey to determine if $\mathrm{PtD}$ is feasible in the U.S.; they used a questionnaire survey with construction project clients, designers, builders, and contractors to understand the PtD opinions of these construction project participants. Their research results showed that designers have the lowest level of understanding of PtD [28].

Given the implications of the aforementioned previous studies, construction project participants clearly have a different perspective on DfS, as they have different levels of understanding, responsibility, and tasks. Therefore, a comparative analysis of the priorities in relation to improving DfS considered from the standpoints of the construction project participants should be conducted to improve DfS in South Korea. In addition, the priorities for DfS improvement by career level should be determined.

It is challenging to analyze the perspectives of construction project participants. Accordingly, questionnaire surveys should be conducted with construction project participants and according to different career levels $[10,28]$. Subsequently, using absolute and relative evaluation methods, the perspective of construction participants can be analyzed from various aspects.

Therefore, in this study, eight alternatives were deduced for improving the DfS process in South Korea based on an analysis of previous relevant studies, after which the perceptions of improvements as held by construction project participants and based on different career levels were compared using weighting factors.

\section{Materials and Methods}

As shown in Figure 1, this study involves three steps: (1) the definition of DfS improvement alternatives, (2) the carrying out of a questionnaire survey, and (3) the calculation and analysis of the weighting factors.

First, based on previous studies related to DfS, eight DfS improvement alternatives for South Korea were selected and explained. Second, a questionnaire survey was utilized to determine the respondents' perceptions of the importance of DfS improvement. The 27 respondents here all had links to the construction industry. They consisted of five clients, five designers, eight contractors, four construction managers, and five researchers. Nine respondents had less than ten years of experience with DfS, and 18 had more than ten years of experience. This study identified the perspective of construction participants, as mentioned above, using the concepts of absolute importance and relative 
importance. An Analytical Hierarchy Process (AHP) is one of the most common methodologies to identify the relative importance. AHP does not rely on the criteria of the respondents. Through a consistency ratio, the reliability of AHP is evaluated. Therefore, in previous studies with 15, 16, and 19 respondents, it was possible to obtain meaningful results using AHP [36-38]. Accordingly, 27 respondents are an appropriate sample given the use of the AHP methodology in this study, and the reliability of AHP was substantiated using the consistency ratio. Based on the results of the aforementioned questionnaire survey, the absolute importance levels of the eight DfS improvement alternatives were identified. Several statistical analyses were conducted to validate the questionnaire survey and verify the independence. Third, a fuzzy analytical hierarchy process (F-AHP) analysis was conducted with the following three criteria: (1) the perspectives of all respondents, (2) the perspectives of participants from construction projects, and (3) the career level. The importance levels of the eight DfS improvement alternatives in terms of the three aforementioned criteria as determined via the F-AHP analysis are presented below.

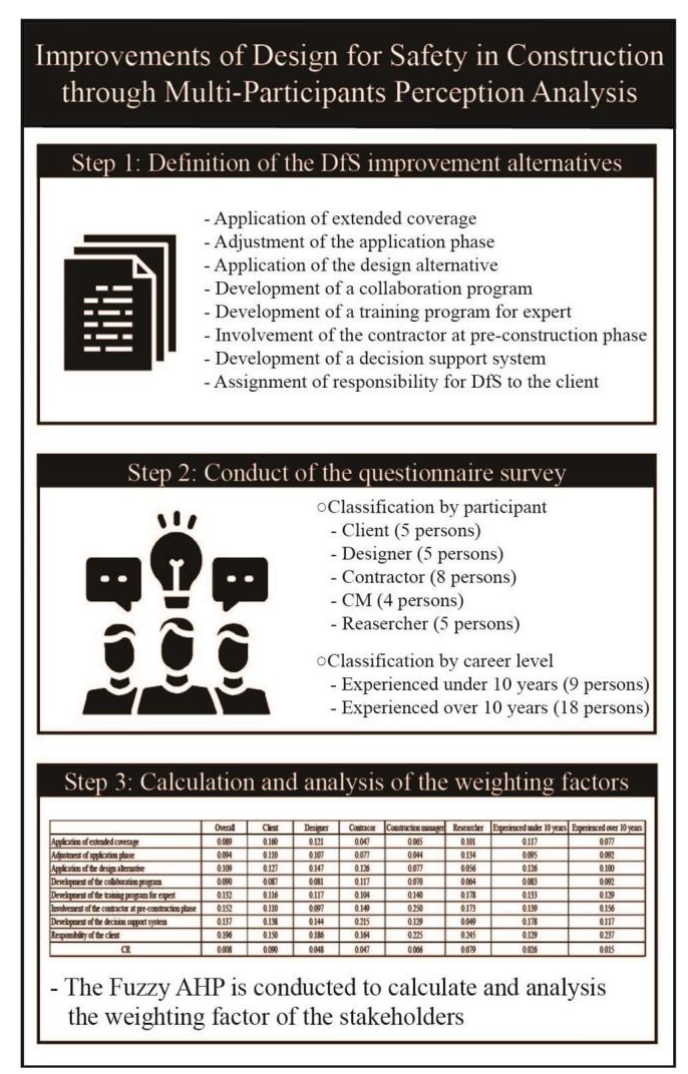

Figure 1. Research process.

\subsection{Definition of the DfS Improvement Alternatives}

As mentioned earlier, eight DfS improvement alternatives were deduced in this study, and the priority of such DfS alternatives for the improvement of DfS in South Korea as perceived by all respondents and the construction project participants, and by career level, are presented herein. Toole and Gambatese (2008) suggested four PtD alternatives through a literature review to improve $\mathrm{PtD}$. Therefore, this study analysis previous studies, reports, and laws to deduce the DfS improvement alternatives, with eight found after this process [15].

As shown in Table 1, relevant studies, reports, and laws were considered before suggesting the following eight DfS improvement alternatives: (i) the application of extended coverage, (ii) adjustment of the application phase, (iii) application of the design alternatives, (iv) the development of a collaboration program, (v) the development of a training program for experts, (vi) involvement of 
the contractor in the pre-construction phase, (vii) the development of a decision support system, and (viii) the assignment of responsibility for DfS to the client.

Table 1. Definitions of the Design for Safety (DfS) improvement alternatives.

\begin{tabular}{ccc}
\hline Code & Alternative & Reference \\
\hline C01 & Application of extended coverage & {$[11] ;[12] ;[13] ;[14] ;[17] ;[20] ;[27] ;[28] ;[30]$} \\
C02 & Adjustment of the application phase & {$[15] ;[17] ;[30] ;[31]$} \\
C03 & Application of the design alternative & {$[5] ;[11] ;[13] ;[14] ;[17]$} \\
C04 & Development of a collaboration program & {$[17] ;[19] ;[27] ;[35]$} \\
C05 & Development of a training program for experts & {$[6] ;[11] ;[14] ;[17] ;[27]$} \\
C06 & Involvement of the contractor in the & {$[6] ;[15] ;[17] ;[27] ;[28]$} \\
C07 & pre-construction phase & {$[12] ;[31] ;[33] ;[35] ;[39] ;[40]$} \\
C08 & Development of a decision support system & {$[11] ;[17] ;[24] ;[28] ;[29] ;[40]$} \\
\hline
\end{tabular}

Explanations of the DfS Improvement Alternatives

(i) Application of extended coverage: In South Korea, DfS is applied only to public construction projects that exceed a specific size (e.g., buildings with more than ten stories, buildings with excavations exceeding $10 \mathrm{~m}$ ) [17]. In addition, in South Korea, the number of private construction projects is more than three times the number of public construction projects [19]. Thus, the number of DfS-eligible construction projects in South Korea is very small compared to the size of the overall construction industry in the country.

On the other hand, CDM in the UK can be applied to construction projects with a construction period of 30 days or more or with more than 20 construction workers, as well as to those with more than 500 construction workers per day [11]. In addition, Safe Design in Australia is applied to all construction projects worth over AUD \$250,000 [13], and DfS in Singapore is applied to all construction projects worth over SGD $\$ 100,000$ [14]. As such, overseas DfS is applied to all construction projects regardless of whether they are public or private [30]. In addition, PtD in the U.S. is a national strategy that has not been legislated, unlike in other countries, and its application to construction projects is simply a recommendation and not a requirement. The U.S., however, is attempting to induce the application of PtD by providing extra points for LEED certification to those cases where PtD is implemented [12].

(ii) Adjustment of the application phase: DfS in South Korea is supposed to be implemented upon $80 \%$ completion of the construction document preparation phase [17], when most of the design outputs have been completed. In this case, however, even if a situation where a design change is required through the DfS process occurs, there is no institutional basis for additional costs and design period extensions. Therefore, it is not easy for construction project clients and designers proactively to suggest design alternatives and reflect these in the construction document. With the application of DfS, a design change requires more collaboration, additional processes, and incurs more costs as the construction life cycle progresses [28,32]. According to the MacLeamy curve, the impact of a change in the construction project decreases gradually from the design phase to the construction and operating and maintenance phases. Conversely, the cost required for the implementation of a change in the construction project increases as the operating and maintenance phases approach [41]. Therefore, DfS is more effective when implemented in the conceptual phase, which is the initial design stage. In addition, it is advisable to implement DfS upon 10,30,60, and 90\% completion of the design phase [27,33].

(iii) Application of design alternatives: According to DfS-related laws in South Korea, the implementation of DfS is mandatory in public construction projects, but there is no obligation to apply design alternatives [17]. Therefore, even if the design changes due to the presence of risk factors, such a change may not be applied depending on the contractor's decision. On the other hand, the most important part of CDM in the U.S. is the application of the designer's design alternative and its delivery to the construction project participants [5,11]. In other words, it is most important 
to change the design in light of the design alternative and thus to remove or reduce the risks during the construction phase. Even with DfS in Singapore and Safe Design in Australia, discovering and applying risk factors found in the design phase to a design alternative is required [13,14].

(iv) Development of a collaboration program: DfS in South Korea requires that upon $80 \%$ completion of the construction document, the designer must create a proposed design alternative through the DfS process and submit it to the client. Then, if and when the client approves it, it is delivered to the contractor. The contractor, in turn, creates a safety management plan including the design alternative for the construction phase [17]. Thus, the design alternative proposed through DfS is created solely by the designer, and no collaboration is done among the construction project participants [19].

The designer, however, lacks knowledge about the site conditions, construction methods, construction periods, and safety management issues [35]. This notwithstanding, the designer creates a design alternative and the client examines it to determine its adequacy. Thus, it may happen that the contractor will find it difficult to apply the design alternative. Toole et al. (2017) presented results of interviews with designers and other construction project participants. It was established that collaboration among the designers and other construction project participants is key to DfS in the design phase [27].

(v) Development of a training program for experts: DfS was introduced in South Korea only recently. Accordingly, designers still lack knowledge about it and about safety management [17]. In previous relevant studies, designers recognized only $50 \%$ of all construction hazards in the construction phase [6]. For this reason, it is not desirable to apply the DfS component created by the designer in the construction phase. Therefore, to implement DfS effectively, it is experts with professional knowledge who should implement the DfS process considering the site conditions, construction methods, and safety management principles [27]. In South Korea, however, an expert is elected only when the client determines that an expert is needed. In addition, there is no separate standard for experts [17].

Meanwhile, as the need for DfS experts increases, CDM 2015 in the UK seeks to replace the existing coordinator with a principal designer and to strengthen the responsibility of this person as a DfS expert [11]. In Singapore, only experts with a Registered Professional Engineer/Registered Architect certificate or more than ten years of experience in design work become DfS professionals after completing a specialized training course [14].

(vi) Involvement of the contractor in the pre-construction phase: As mentioned earlier, to implement the DfS process efficiently, collaboration among the construction project participants is important. In particular, as the construction method varies depending on the building time and site conditions of the construction project, construction methods suitable for the site conditions should be considered in the design phase. Therefore, it is very important for a contractor who has extensive knowledge of construction methods to participate in the early stages of the design phase [15].

In conventional design-bid-build projects, however, the contractor cannot participate in the design phase because the design is completed before the contractor is selected $[27,28]$. For the contractor to participate in the design phase, a construction project delivery method in which the design and construction start at the same time or the construction starts during the design process is required. In this regard, an integrated construction project delivery method that uses a collaborative design and construction approach is effective for the contractor to be able to participate in the design phase [6]. In South Korea, however, it is stipulated that DfS is applicable only to design-bid-build construction projects [17]. In addition, because construction project contracts other than the design-bid-build types are rarely concluded even for construction projects where there is no obligation to apply DfS, it is difficult for the contractor to participate in the design phase.

(vii) Development of a decision support system: When DfS is applied, it is not easy for the designer, who lacks knowledge about construction methods, to predict accidents that may occur during the construction phase [39]. As such, DfS has a higher degree of operation difficulty. Therefore, 
a decision support system is needed to provide the designer with the information required for the implementation of DfS [31,33,35,40]. In South Korea, the Korea Infrastructure Safety Corporation provides approximately 450 checklists through a risk factor profile, but this is not sufficient to help with the actual implementation of DfS. On the other hand, PtD in the U.S. provides designers with various decision support systems, such as SliDeRulE, SCSH, PtD list, and DfS Toolbox, to supplement insufficient PtD information [12].

(viii) Assignment of responsibility for DfS to the client: According to the Design for Safety Business Manual, the construction project client is involved in the entire DfS process, from providing the designer with construction-project-related information to reviewing and approving design alternatives when implementing DfS [17]. As the client is involved in the entire construction process, the client can have a profound impact on the construction safety. If the client actively participates in construction safety management, the number of accidents at the construction site decreases [42]. Traditionally, however, the client does not play a substantial role in the construction phase but delegates the client's role to the construction manager [28]. It was found that in South Korea, although the client recognizes the client's role as a client at the construction site, the client does not have an interest in construction safety management. This situation arises because in DfS in South Korea, there are no separate laws pertaining to the responsibilities of construction project clients [24,29].

In an increasing number of lawsuits related to construction accidents, it is established that the client has greater responsibility for construction accidents. As such, the responsibility of construction project clients for construction accidents has become more important worldwide [28]. In line with this trend, CDM 2015 in the UK has strengthened the responsibilities of construction project clients with regard to construction accidents [11,29].

\subsection{Conduct of the Questionnaire Survey}

As mentioned earlier, the questionnaire survey in this study was conducted among 27 respondents related to the construction industry (five clients, five designers, eight contractors, four construction managers, and five researchers). Information about these respondents is summarized in Table 2. As in South Korea DfS is applied only to public construction projects, a questionnaire survey was conducted on construction project clients working at public institutions. The respondents here were between 20 and 50, with 11 of 27 respondents in their 40s. In terms of career levels, nine respondents had less than ten years of experience, and 18 respondents had more than 10 years of experience. In this study, the career level was investigated on a ten-year basis because in South Korea, experience of at least ten years is required to become a person in charge of a construction project. In addition, a DfS professional in Singapore should have had more than 10 years of design experience [14,20].

Table 2. Information on the questionnaire survey respondents.

\begin{tabular}{|c|c|c|c|c|c|}
\hline \multicolumn{6}{|c|}{ Information on the Questionnaire Survey Respondents } \\
\hline Age & 20 years & 30 years & & 40 years & 50 years \\
\hline & & & & $11(40.74 \%)$ & \\
\hline Career level & \multicolumn{2}{|c|}{$\begin{array}{l}\text { Experienced under } 10 \text { years } \\
\qquad 9(33.33 \%)\end{array}$} & \multicolumn{3}{|c|}{$\begin{array}{c}\text { Experienced over } 10 \text { years } \\
18(66.67 \%)\end{array}$} \\
\hline $\begin{array}{c}\text { Construction project } \\
\text { participant }\end{array}$ & $\begin{array}{c}\text { Client } \\
5(18.52 \%)\end{array}$ & $\begin{array}{c}\text { Designer } \\
5(22.22 \%)\end{array}$ & $\begin{array}{l}\text { Contractor } \\
8(29.63 \%)\end{array}$ & $\begin{array}{c}\text { Construction manager } \\
4(11.11 \%)\end{array}$ & $\begin{array}{c}\text { Researcher } \\
5(18.52 \%)\end{array}$ \\
\hline
\end{tabular}

The questionnaire survey used in this study was divided into two sections. The first section consisted of items for identifying the absolute importance of the eight aforementioned DfS improvement alternatives. The importance of each of the eight DfS improvement alternatives was evaluated using a five-point Likert scale (1 point: not important; 2 points: less important; 3 points: neutral; 4 points: important; 5 points: very important) [21,43]. Cronbach's alpha was utilized for consistency and reliability of the questionnaire survey. The Cronbach's alpha result for the questionnaire survey 
was 0.857 . Thus, the questionnaire survey was shown to be feasible for use in terms of consistency and reliability [44]. The second section of the questionnaire survey consisted of items for examining the relative priority levels of the eight DfS improvement alternatives as perceived by the respondents overall and the construction project participants, and based on the career level. It consisted of pairwise comparison questions in relation to the F-AHP analysis, for which a nine-point Likert scale (1 point: equal importance; 3 points: moderate importance of one over another; 5 points: strong importance of one over another; 7 points: very strong importance of one over another; 9 points: extreme importance of one over another; $2,4,6$, and 8 points: intermediate values; reciprocals: reciprocals for inverse comparison) was utilized [45]. Based on the results of the questionnaire survey, the F-AHP analysis was conducted in three steps: (1) from the overall respondents' perspective, (2) from the construction project participants' perspectives, and (3) by career level.

\subsubsection{Degrees of Importance of the Eight DfS Improvement Alternatives}

As mentioned earlier, a questionnaire survey was conducted in this study to identify the absolute importance of the eight DfS improvement alternatives defined in the chapter entitled "Definition of the DfS Improvement Alternatives" using a five-point Likert scale. The results of the questionnaire survey are presented in Table 3, in the order of 'Assignment of responsibility for DfS to the client' (AVG 3.926; STD 0.90), 'Involvement of the contractor in the pre-construction phase' (AVG 3.926; STD 1.02), 'Development of a collaboration program' (AVG 3.852; STD 0.93), 'Adjustment of the application phase' (AVG 3.852; STD 0.76), 'Development of a training program for experts' (AVG 3.704; STD 0.94), 'Application of a design alternative' (AVG 3.630; STD 0.91), 'Development of a decision support system' (AVG 3.630; STD 0.95), and 'Application of extended coverage' (AVG 3.407; STD 0.91). The respondents showed a rising level of awareness of these eight DfS improvement alternatives, with an average of three or more points (3.63-3.93).

Table 3. Investigation of the DfS improvement alternatives.

\begin{tabular}{|c|c|c|c|c|c|}
\hline \multicolumn{6}{|c|}{ Questionnaire for the Investigation of the DFS Improvement Alternatives } \\
\hline & $\begin{array}{c}\text { Not } \\
\text { Important } \\
\text { (1 Point) }\end{array}$ & $\begin{array}{c}\text { Less } \\
\text { Important } \\
\text { (2 Points) }\end{array}$ & $\begin{array}{l}\text { Neutral } \\
\text { (3 Points) }\end{array}$ & $\begin{array}{l}\text { Important } \\
\text { (4 Points) }\end{array}$ & $\begin{array}{c}\text { Very } \\
\text { Important } \\
\text { (5 Points) }\end{array}$ \\
\hline \multirow{2}{*}{ Application of extended coverage } & $0(0 \%)$ & $5(18.52 \%)$ & $9(33.33 \%)$ & $10(37.04 \%)$ & $3(11.11 \%)$ \\
\hline & AVG & 3.407 & STD & \multicolumn{2}{|c|}{0.93} \\
\hline \multirow{2}{*}{ Adjustment of the application phase } & $0(0 \%)$ & $1(3.70 \%)$ & $7(25.93 \%)$ & $14(51.85 \%)$ & $5(18.52 \%)$ \\
\hline & AVG & 3.852 & STD & \multicolumn{2}{|c|}{0.77} \\
\hline \multirow{2}{*}{ Application of the design alternative } & $1(3.70 \%)$ & $1(3.70 \%)$ & $9(33.33 \%)$ & $12(44.44 \%)$ & $4(14.81 \%)$ \\
\hline & AVG & 3.630 & STD & \multicolumn{2}{|c|}{0.93} \\
\hline \multirow{2}{*}{ Development of a collaboration program } & $0(0 \%)$ & $3(11.11 \%)$ & $5(18.52 \%)$ & $12(44.44 \%)$ & $7(25.93 \%)$ \\
\hline & AVG & 3.852 & STD & \multicolumn{2}{|c|}{0.95} \\
\hline \multirow{2}{*}{ Development of a training program for experts } & $0(0 \%)$ & $4(14.81 \%)$ & $5(18.52 \%)$ & $13(48.15 \%)$ & $5(18.52 \%)$ \\
\hline & AVG & 3.704 & STD & \multicolumn{2}{|c|}{0.95} \\
\hline \multirow{2}{*}{$\begin{array}{l}\text { Involvement of the contractor in the } \\
\text { pre-construction phase }\end{array}$} & $0(0 \%)$ & $3(11.11 \%)$ & $6(22.22 \%)$ & $8(29.63 \%)$ & $10(37.04 \%)$ \\
\hline & AVG & 3.926 & STD & \multicolumn{2}{|c|}{1.04} \\
\hline \multirow{2}{*}{ Development of a decision support system } & $0(0 \%)$ & $3(11.11 \%)$ & $8(29.63 \%)$ & $11(40.74 \%)$ & $5(18.52 \%)$ \\
\hline & AVG & 3.667 & STD & \multicolumn{2}{|c|}{0.92} \\
\hline \multirow{2}{*}{ Assignment of responsibility for DfS to the client } & $0(0 \%)$ & $2(7.41 \%)$ & $6(22.22 \%)$ & $11(40.74 \%)$ & $8(29.63 \%)$ \\
\hline & AVG & 3.926 & STD & \multicolumn{2}{|c|}{0.92} \\
\hline
\end{tabular}

\subsubsection{Validation of the Eight DfS Alternatives and Construction Participants}

The independence analysis is conducted using SPSS 18. An analysis of variance (ANOVA) and a t-test are utilized to identify the validity among the eight DfS alternatives, five construction project 
participants, and two career levels. First, ANOVA conducts a comparison of more than two populations and the t-test conducts a comparison of two populations. Thus, the eight DfS alternatives and five construction project participants are analyzed by the ANOVA and the two career levels are analyzed by a t-test. The hypotheses of the ANOVA and t-test are as follows. $\mathrm{H}_{0}$ (null hypothesis) states that all groups' means are identical, while $\mathrm{H}_{1}$ (alternative hypothesis) posits a difference in at least one group's mean. Therefore, through the ANOVA and the t-test, validation can be ascertained [46-51]. Table 4 shows the results of the ANOVA and the t-test.

Table 4. Result of the independent analysis.

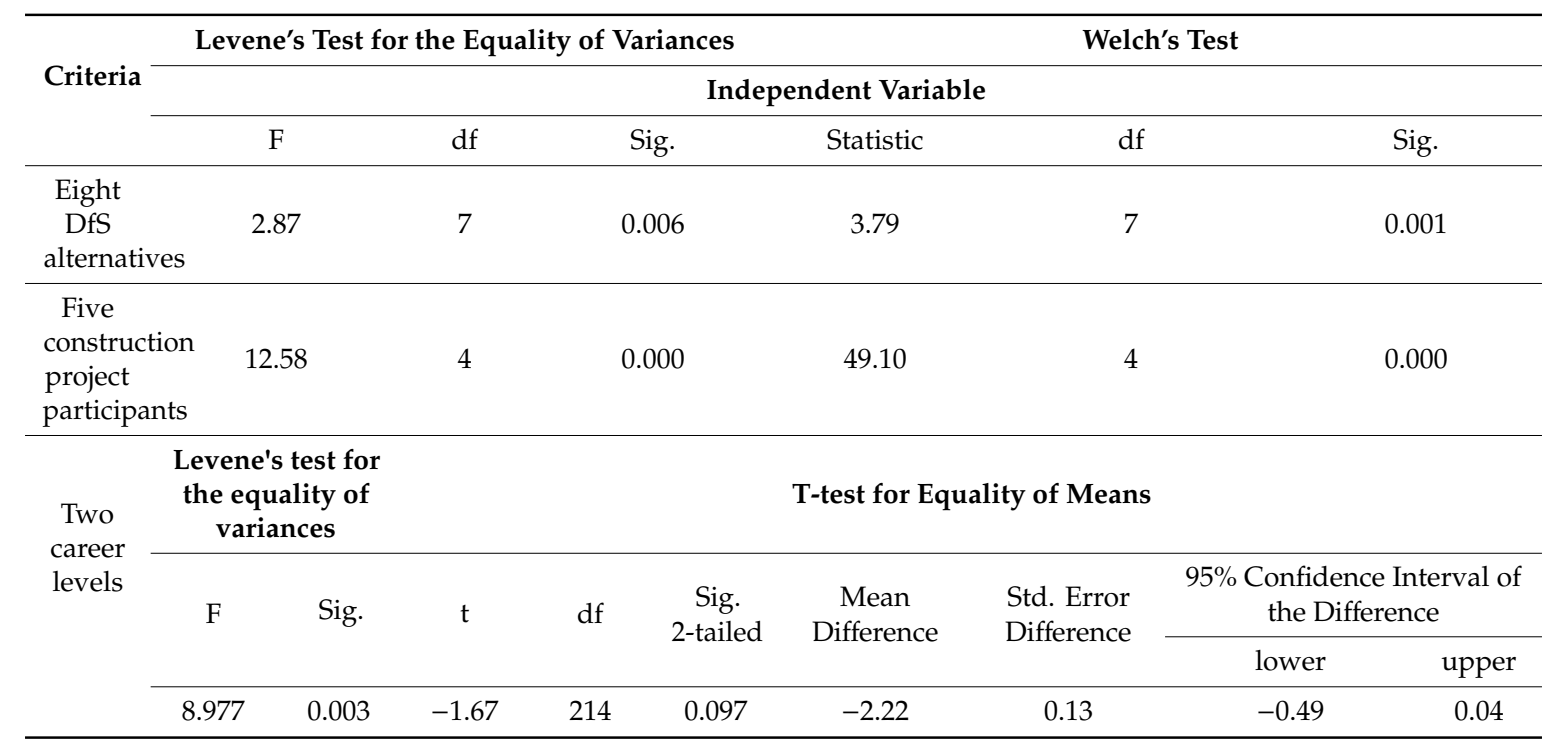

Prior to the ANOVA and t-test, Levene's test was used to analyze the equality of variances. Because the result of the $p$-value was 0.000 , equality of the variances cannot be assumed. Thus, Welch's test of a variance analysis was carried out instead of a one-way ANOVA [52]. The result of Welch's test indicates that the $p$-value is lower than 0.05 ; therefore, the eight DfS alternatives and five construction project participants are valid. The results of the t-test indicated that the $p$-value is 0.068 ( $p$-value $<0.01$ ). Thus, the two career levels are validated.

\subsection{Calculation and Analysis of the Weighting Factors}

\subsubsection{Explanation of F-AHP}

AHP was developed by Saaty in 1980 [53]. It is a methodology that stratifies decision-making problems (e.g., goal-criteria alternatives) and systematically evaluates the relative importance of various alternatives through a pairwise comparison of the elements of a hierarchy. In addition, it can measure the consistency of results on importance through what is termed the consistency ratio (CR). Here, the AHP analysis proceeds as follows: (i) the decision-making problems are stratified into goals, criteria, and alternatives; (ii) a pairwise comparison of the decision-making elements is conducted at a given level of the hierarchy, with the pairwise comparison matrix calculated using Equation (1); (iii) the pairwise comparison matrix is converted into a normalized matrix calculated using Equation (2), and the average value of each row of the normalized matrix is calculated to derive a weighting factor; and (iv) to prove the effectiveness of the weighting factor, the CR calculated using Equation (4) is presented using the consistency index (CI) calculated using Equation (3) and the random index (RI) presented in Table 5 [53-55].

$$
A=\left(\begin{array}{ccc}
a_{11} & \cdots & a_{1 n} \\
\vdots & \ddots & \vdots \\
a_{n 1} & \cdots & a_{n n}
\end{array}\right)
$$


Table 5. Random Index for the calculation of consistency ratio (CR).

\begin{tabular}{ccccccccccc}
\hline $\mathbf{n}^{(\mathbf{1})}$ & $\mathbf{1}$ & $\mathbf{2}$ & $\mathbf{3}$ & $\mathbf{4}$ & $\mathbf{5}$ & $\mathbf{6}$ & $\mathbf{7}$ & $\mathbf{8}$ & $\mathbf{9}$ & $\mathbf{1 0}$ \\
\hline $\mathrm{RI}^{(2)}$ & 0.00 & 0.00 & 0.58 & 0.90 & 1.12 & 1.24 & 1.32 & 1.41 & 1.45 & 1.49 \\
\hline \multicolumn{7}{c}{${ }^{(1)} \mathrm{n}: \mathrm{n}$ is the number of alternatives; ${ }^{(2)} \mathrm{RI}$ is the random index as defined by Saaty }
\end{tabular}

Here, matrix $\mathrm{A}$ is the comparison matrix, $a_{i j}$ is the $j$-th alternative at the $i$-th alternative, and $n$ is the number of alternatives.

$$
P=\left(\begin{array}{ccc}
p_{11} & \cdots & p_{1 n} \\
\vdots & \ddots & \vdots \\
p_{n 1} & \cdots & p_{n n}
\end{array}\right)
$$

In this equation, matrix $P$ is the normalized matrix and $P_{i j}$ is $a_{i j}$ divided by the sum of the $a_{i j}$ columns.

$$
C I=\left(\lambda_{\max }-n\right) /(n-1)
$$

Here, $\lambda_{\max }$ is the maximum Eigen value of the comparison matrix,

$$
C R=C I / R I
$$

where $C R$ is the consistency ratio of the respondents and $R I$ is the random index.

AHP can analyze differences in opinions between the respondent groups because it can establish a plan by reflecting the perceptions of all construction participants. However, the traditional AHP cannot easily reflect the opinions of respondents precisely because with uncertainty of information, it is difficult to provide an exact numerical point for a perception [56-58]. Accordingly, to overcome this problem, fuzzy AHP (F-AHP) is utilized in this study. The triangular fuzzy value for a pair-wise comparison can take the features of the interval perception and the most likely values. F-AHP utilizes the following equations. First, the judgement matrix $F_{n \times n}$, which is the ratio of the interval values, is calculated by Equation (5). Second, the value of the fuzzy synthetic extent about the ith object (Pi) is calculated by Equation (6). Third, the possibility degree $\mu(d)$ can be expressed by Equation (7). Forth, the weighting vector of F-AHP can be expressed by Equation (8) [56].

$$
F=\left(\begin{array}{ccc}
1 & \cdots & P_{1 n} \\
\vdots & \ddots & \vdots \\
P_{n 1} & \cdots & 1
\end{array}\right)
$$

Here, $P_{1 n}$ is the ratio of the interval value for the first factor and the interval value for the $n$-th factor, and $P_{n 1}$ is the inverse of $P_{1 n}$.

$$
P_{i}=S_{i} \otimes\left[\sum_{i=i}^{n} \sum_{j=i}^{n} P_{f i}^{j}\right]^{-1}
$$

In this equation, $P_{i}$ is the fuzzy synthetic extent to the $i$-th object, $P_{f i}^{j}$ is the fuzzy synthetic extent of the $j$-th factor to the $i$-th object in matrix $F_{n \times n}$ with triangular fuzzy numbers, and $S_{i}$ is the sum of the triangular numbers.

$$
\mu(d)=\left\{\begin{array}{c}
1 \\
0 \\
\frac{l-u}{(m-u)-(m-l)}
\end{array}\right.
$$


Here, $\mu(d)$ is the possibility degree, 1 is the smallest triangular value, $\mathrm{m}$ is the most likely value of the triangular value, and $\mathrm{u}$ is the greatest triangular value,

$$
w=\left(\mu\left(d_{1}\right)^{\prime}, \mu\left(d_{2}\right)^{\prime}, \cdots \mu\left(d_{n}\right)^{\prime}\right)
$$

where $w$ is the weighting factor.

F-AHP is selected to analyze the differences in the perceptions of the degrees of importance of the eight DfS improvement alternatives from the perspectives of the construction project participants and based on the career level.

\subsubsection{Establishment of the AHP Model}

As shown in Figure 2, the AHP model consists of the following: "goal," which is set for the improvement of DfS in South Korea; "criteria" for importance; and "alternative" for the eight DfS improvement alternatives ('Application of extended coverage', 'Adjustment of the application phase', 'Application of a design alternative', 'Development of a collaboration program', 'Development of a training program for experts', 'Involvement of the contractor in the pre-construction phase', 'Development of a decision support system', and 'Assignment of responsibility for DfS to the client').

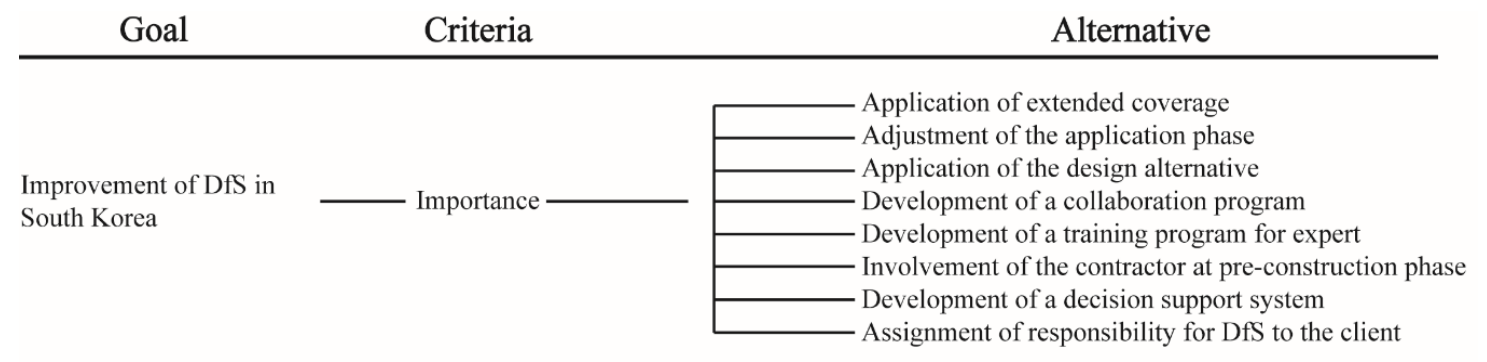

Figure 2. Result of absolute importance of alternatives.

\section{Results and Discussion}

\subsection{Absolute Importance of the DfS Improvement Alternatives from the Overall Respondents' Perspective}

In the chapter entitled "Conduct of the Questionnaire Survey," based on the results of the questionnaire survey, the absolute importance of the eight DfS improvement alternatives is presented. Table 6 and Figure 3 present the absolute importance of the eight DfS improvement alternatives according to the construction project participants and career levels, as perceived by the respondents. As mentioned earlier, the respondents overall judged that DfS improvements are needed, as the value of their perceived absolute importance of the eight DfS improvement alternatives was 3.745. For the DfS participants, the researchers, among all construction project participant respondents in this study, accorded utmost importance to the DfS improvement alternatives, with a 4.100 absolute importance value, possibly because researchers have performed various studies to improve DfS $[15,28,43]$ and have come to recognize the importance of DfS in reducing the accident rate in the construction industry. The researchers were followed by the contractors and designers, with absolute importance values of 4.016 and 3.675, respectively. Recognizing the need for DfS improvements, the contractors and the designers also judged that the eight DfS improvement alternatives are important because they are the ones who actually implement DfS. Conversely, the clients and the construction managers, who are responsible for DfS, did not accord much importance to the eight DfS improvement alternatives. In terms of the career level, the respondents overall with experience of less than ten years and those with experience of more than ten years thought highly of the DfS improvement alternatives, with absolute importance values of 3.597 and 3.819, respectively. Therefore, the respondents with higher career levels felt the limitations of safety management in the construction phase and emphasized the importance of DfS for safety management in the design phase. 
Table 6. Results of the absolute importance of the DfS improvement alternatives.

\begin{tabular}{|c|c|c|c|c|c|c|c|c|}
\hline & Overall & Client & Designer & Contractor & $\begin{array}{c}\text { Construction } \\
\text { Manager }\end{array}$ & Researcher & $\begin{array}{c}\text { Experienced } \\
\text { under } 10 \text { Years }\end{array}$ & $\begin{array}{l}\text { Experienced } \\
\text { over } 10 \text { Years }\end{array}$ \\
\hline Application of extended coverage & 3.407 & 2.400 & 3.400 & 3.750 & 3.333 & 4.000 & 3.000 & 3.611 \\
\hline Adjustment of the application phase & 3.852 & 2.800 & 3.800 & 4.125 & 3.667 & 4.200 & 3.889 & 3.833 \\
\hline Application of the design alternative & 3.630 & 3.000 & 3.800 & 4.125 & 3.000 & 3.400 & 3.556 & 3.667 \\
\hline Development of a collaboration program & 3.852 & 3.400 & 3.800 & 4.250 & 2.667 & 4.000 & 3.556 & 4.000 \\
\hline Development of a training program for experts & 3.704 & 3.200 & 3.200 & 3.625 & 3.333 & 4.400 & 3.444 & 3.833 \\
\hline $\begin{array}{l}\text { Involvement of the contractor in } \\
\text { the pre-construction phase }\end{array}$ & 3.926 & 2.800 & 3.400 & 4.750 & 3.667 & 4.200 & 3.556 & 4.111 \\
\hline Development of a decision support system & 3.667 & 2.800 & 3.800 & 3.625 & 3.667 & 4.000 & 4.111 & 3.444 \\
\hline Assignment of responsibility for DfS to the client & 3.926 & 3.000 & 4.200 & 3.875 & 3.667 & 4.600 & 3.667 & 4.056 \\
\hline AVG & 3.745 & 2.925 & 3.675 & 4.016 & 3.375 & 4.100 & 3.597 & 3.819 \\
\hline
\end{tabular}



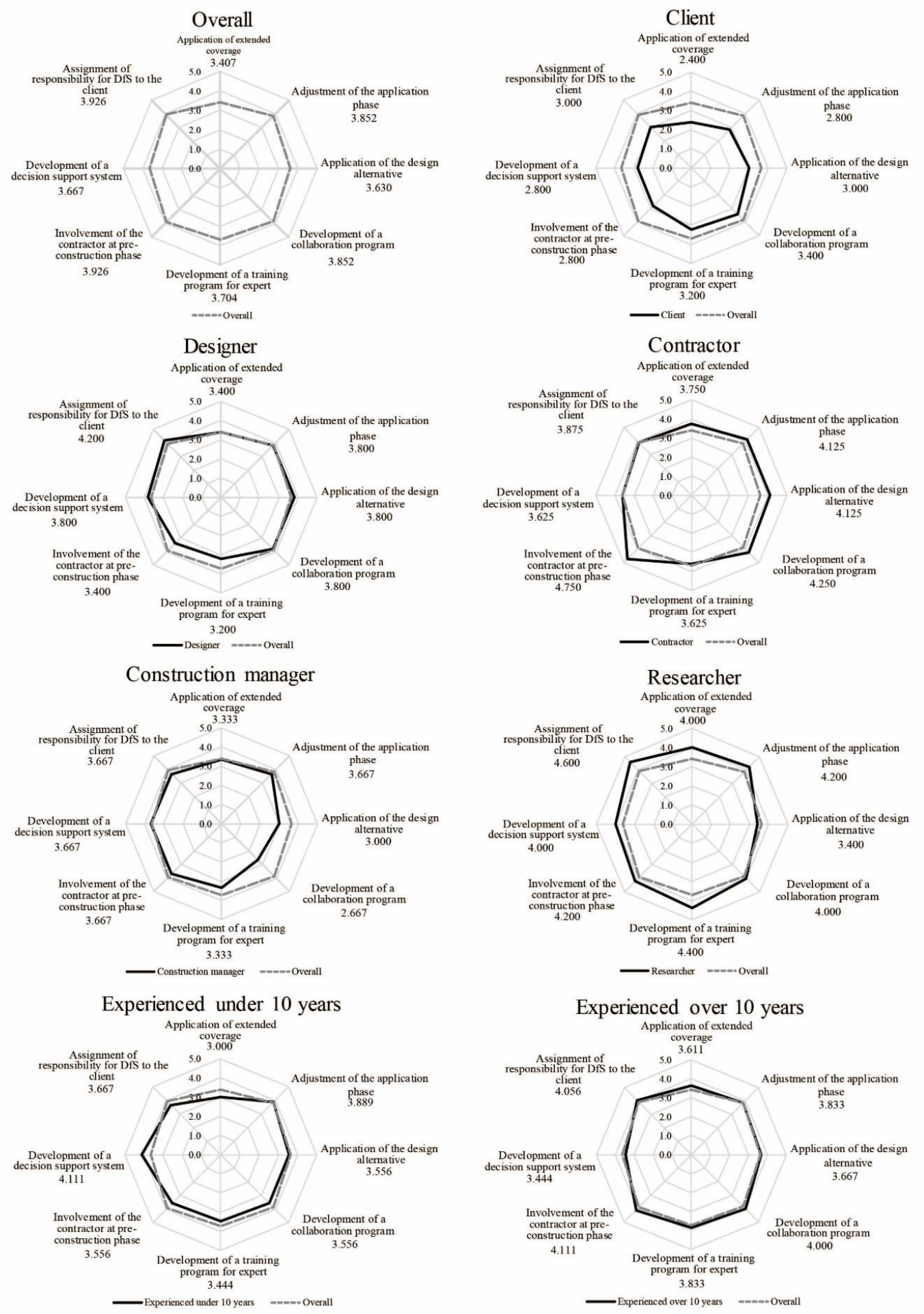

Figure 3. Result of absolute importance of DfS alternatives.

\subsection{Relative Importance of the DfS Improvemeent Altenatives from the Overall Respondents' Perspectives}

To identify the top priority among the eight aforementioned DfS improvement alternatives, the relative importance of each of the alternatives as perceived by the 27 respondents was analyzed using F-AHP. A comparative analysis of the relative importance of each of the alternatives as perceived by the construction project participants and based on the career level was performed using F-AHP. It was found that all CRs were less than 0.1 , which provides evidence of the consistency of the responses. The results of the F-AHP analysis are presented in Figure 4 and Table 7. 

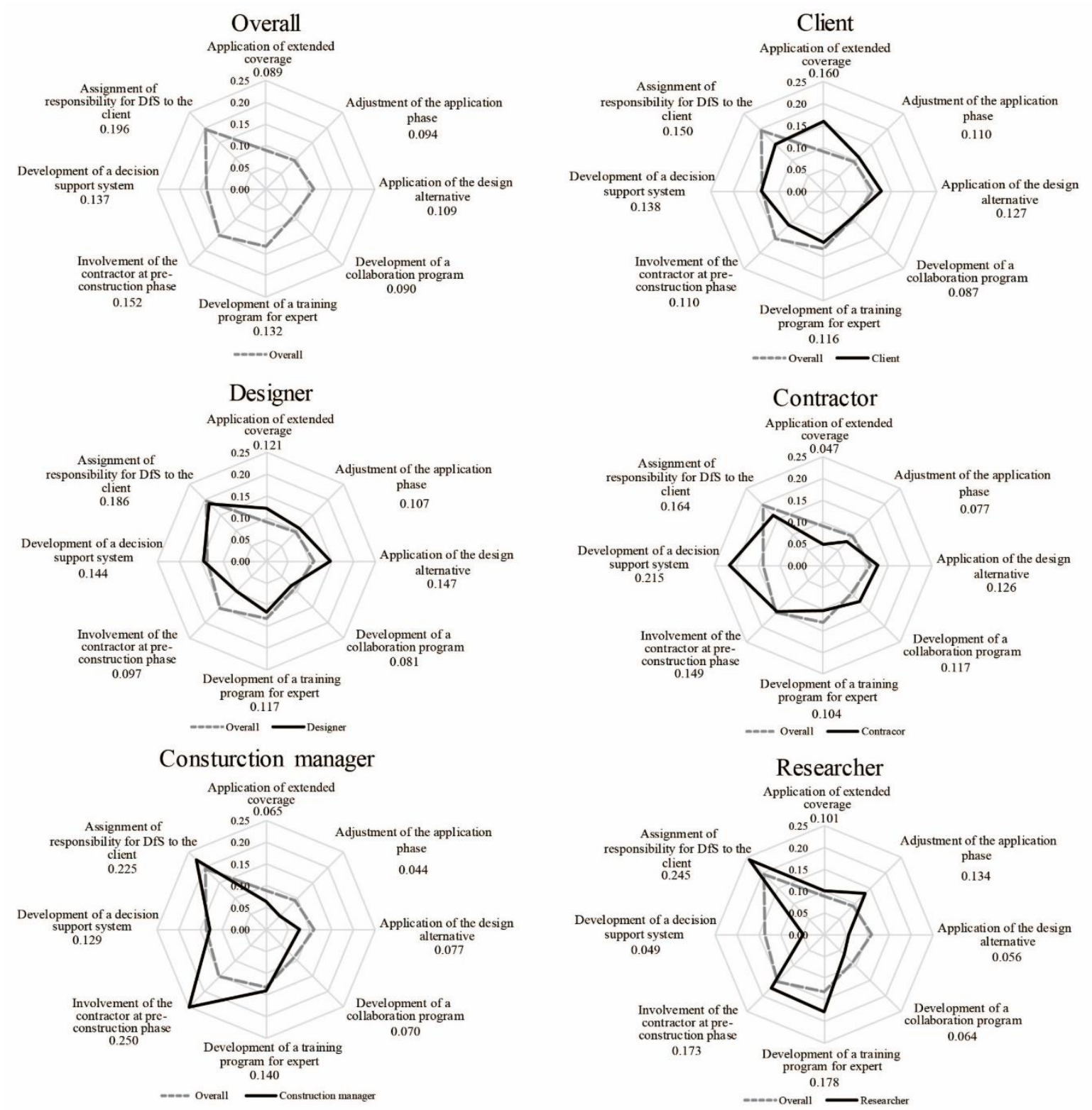

Experienced under 10 years
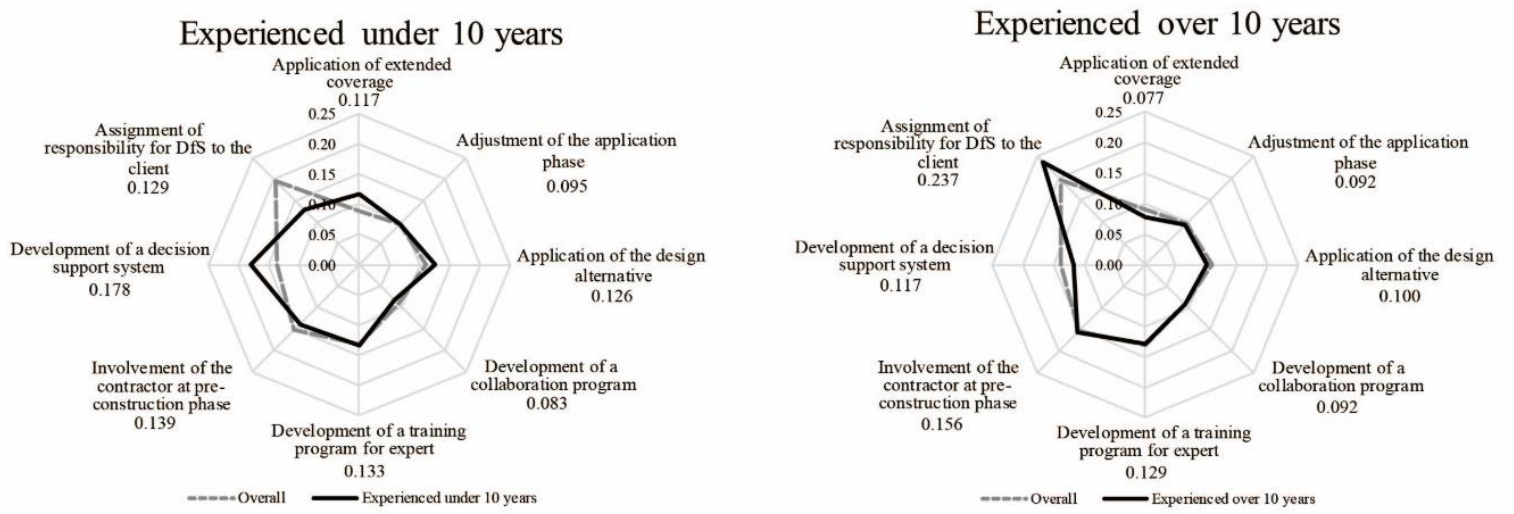

Figure 4. Results of importance's fuzzy-analytical hierarchy process (F-AHP) analysis. 
Table 7. Results of the F-AHP analysis of the importance of the DfS improvement alternatives.

\begin{tabular}{|c|c|c|c|c|c|c|c|c|}
\hline & Overall & Client & Designer & Contractor & $\begin{array}{c}\text { Construction } \\
\text { Manager }\end{array}$ & Researcher & $\begin{array}{c}\text { Less than } 10 \\
\text { Years } \\
\text { Experience }\end{array}$ & $\begin{array}{c}\text { More than } 10 \\
\text { Years } \\
\text { Experience }\end{array}$ \\
\hline Application of extended coverage & $0.089(8)$ & $0.160(1)$ & $0.121(4)$ & $0.047(8)$ & $0.065(7)$ & $0.101(5)$ & $0.117(6)$ & $0.077(8)$ \\
\hline Adjustment of the application phase & $0.094(6)$ & $0.110(6)$ & $0.107(6)$ & $0.077(7)$ & $0.044(8)$ & $0.134(4)$ & $0.095(7)$ & $0.092(7)$ \\
\hline Application of the design alternative & $0.109(5)$ & $0.127(4)$ & $0.147(2)$ & $0.126(4)$ & $0.077(5)$ & $0.056(7)$ & $0.126(5)$ & $0.100(5)$ \\
\hline Development of a collaboration program & $0.090(7)$ & $0.087(8)$ & $0.081(8)$ & $0.117(5)$ & $0.070(6)$ & $0.064(6)$ & $0.083(8)$ & $0.092(6)$ \\
\hline Development of a training program for experts & $0.132(4)$ & $0.116(5)$ & $0.117(5)$ & $0.104(6)$ & $0.140(3)$ & $0.178(2)$ & $0.133(3)$ & $0.129(3)$ \\
\hline $\begin{array}{l}\text { Involvement of the contractor in the } \\
\text { pre-construction phase }\end{array}$ & $0.152(2)$ & $0.110(6)$ & $0.097(7)$ & $0.149(3)$ & $0.250(1)$ & $0.173(3)$ & $0.139(2)$ & $0.156(2)$ \\
\hline Development of a decision support system & $0.137(3)$ & $0.138(3)$ & $0.144(3)$ & $0.215(1)$ & $0.129(4)$ & $0.049(8)$ & $0.178(1)$ & $0.117(4)$ \\
\hline Assignment of responsibility for DfS to the client & $0.196(1)$ & $0.150(2)$ & $0.186(1)$ & $0.164(2)$ & $0.225(2)$ & 0.245 (1) & $0.129(4)$ & $0.237(1)$ \\
\hline $\mathrm{CR}$ & 0.008 & 0.090 & 0.048 & 0.047 & 0.066 & 0.079 & 0.026 & 0.015 \\
\hline
\end{tabular}

${ }^{*}$ Remarks 


\subsection{Relative Importance of DfS Improvement Alternatives from the Construction Project Participants' Perspective}

4.3.1. Relative Importance of DfS Improvement Alternatives from the Construction Project Client's Perspective

As shown in the construction project client graph in Figure 4, the clients accorded greater importance to the 'Application of extended coverage' (0.160) compared to all other respondents. As mentioned earlier, the application of DfS can reduce the number of accidents at construction sites. In South Korea, however, DfS is supposed to be implemented only in public construction projects. Therefore, the client who is responsible for construction safety management seeks to expand the application range of DfS and reduce the number of deaths when delivering the construction project. In addition, the clients accorded less importance to the 'Assignment of responsibility for DfS to the client' (0.138) compared to all other respondents. This suggests that the client who is responsible for the safety of the construction project is not enthusiastic about the strengthening of his responsibility for DfS. This finding is consistent with the result of the study carried out by Langar et al. (2016) [25].

\subsubsection{Relative Importance of DfS Improvement Alternatives from the Construction Project} Designer's Perspective

The designer graph in Figure 4 shows that the result of the designers' perception of the relative importance of the DfS improvement alternatives was similar to the result of all respondents' perceptions of the same. The designers, however, accorded greater importance to the 'Application of a design alternative' (0.147) compared to all other respondents. The designers think highly of the application of a design alternative because in South Korea, it is the contractor who selects design alternatives in the construction phase. Therefore, it is judged that as the designer wants to reflect the design alternative in the construction phase, thinking that the application of a design alternative is more important than the other alternatives. In contrast, the designer respondents considered 'Involvement of the contractor in the pre-construction phase' (0.097) as less important compared to all other respondents. This suggests that because conflicts may arise between the designer and the contractor due to a difference in opinion between them regarding the design progress in the design phase, the designer places less importance on 'Involvement of the contractor in the pre-construction phase'.

\subsubsection{Relative Importance of DfS Improvement Alternatives from the Construction Project Contractors' Perspective}

The contractor graph in Figure 4 shows that the priorities of the contractor respondents in this study with regard to the DfS improvement alternatives were generally similar to those of all other respondents. Unlike all other respondents, however, the contractor respondents placed relative importance on the 'Development of a decision support system' (0.215). This may stem from the fact that the contractors may end up applying a DfS improvement alternative that is not suitable for the site conditions. Therefore, if the designer suggests a DfS improvement alternative considering the site conditions in the design phase through the decision support system, the contractor will be able to apply a suitable DfS improvement alternative in the field. In addition, the contractors accorded greater importance to the 'Development of a collaboration program' (0.117) compared to all other respondents. As mentioned earlier, in South Korea the contractor cannot participate in the design phase because DfS is implemented only in conventional design-bid-build projects. For this reason, the contractor respondents recognized the need for the development of a collaboration program. Meanwhile, the contractors placed less importance on the 'Application of extended coverage' $(0.047)$ compared to all other respondents because coming up with a DfS improvement alternative is not a prerequisite, and the commencement of construction may be delayed due to the extension of the design period.

The numbers within parentheses are the ranks of the alternatives, the numbers shaded in grey are the highest ranked criteria, the boldface and italicized numbers are weighting factors that exceed 
0.20 , the boldface numbers are the weighting factors that exceed 0.15 , and the italicized numbers are the weighting factors that exceed 0.10 .

4.3.4. Relative Importance of DfS Improvement Alternatives from the Construction Project Construction Managers' Perspective

The construction manager graph in Figure 4 shows that the construction manager respondents in this study accorded greater importance to 'Involvement of the contractor in the pre-construction phase' (0.250) compared to all other respondents, possibly because the construction manager is responsible for the management of the construction site as an agent of the client, and this person investigates if the contractor has taken the risk mitigation measures established in the design phase. If the contractor participates in the implementation of DfS in the pre-construction phase, the contractor discovers the risk factors and establishes risk mitigation measures along with the designer. As such, the contractor is expected to have a better understanding of DfS improvement alternatives and implement them faithfully. On the other hand, the construction manager respondents in this study place less importance on the 'Adjustment of the application phase' (0.044), likely because the construction manager takes responsibility for construction management in the construction phase on behalf of the client and thus has no relevance to DfS in the design phase.

4.3.5. Relative Importance of DfS Improvement Alternatives from the Construction Project Researchers' Perspective

As shown in the researcher graph in Figure 4, the results of the researchers' priorities in terms of the DfS improvement alternatives are extremely biased, unlike those in the graphs of all other respondents, which show relatively little variation in the importance accorded to each of the alternatives. The researchers considered the following three DfS improvement alternatives as very important: 'Assignment of responsibility for DfS to the client' (0.245), 'Development of a training program for experts' (0.178), and 'Adjustment of the application phase' (0.134). Unlike the other construction project participants, who implement DfS directly, researchers perform various studies to improve the DfS process $[15,27,42]$. With respect to the safety of the construction project, the number of industrial accidents at construction sites decreases when the construction project client takes an active role in construction safety management [42]. Therefore, the researchers perceived the assignment of responsibility for DfS to the client related to construction safety management as the most important DfS improvement alternative. In addition, the researchers placed more importance on the 'Development of a training program for experts' compared to all other respondents in this study, perhaps because DfS experts in South Korea are not regulated and the researcher respondents felt that a training program for experts must be developed for the effective implementation of the DfS process in South Korea.

\subsection{Relative Importance of the DfS Improvement Alternatives from the Career Level Perspective}

4.4.1. Relative Importance of the DfS Improvement Alternatives from the Perspective of the Respondents with Experienced under 10 years

The graph of the respondents with less than ten years of experience in Figure 4 shows that the respondents with less than ten years of experience considered the DfS improvement alternatives equally important, without significant variations in their relative importance values. This may have occurred because they lack an overall understanding of the DfS process and knowledge of the improvements that need to be made to it due to their relatively short careers. In the same vein, they placed relative importance on the 'Development of a decision support system' (0.178), perhaps due to their lack of knowledge about the DfS process. On the other hand, they assigned less importance to the 'Assignment of responsibility for DfS to the client' (0.129). 
4.4.2. Relative Importance of the DfS Improvement Alternatives from the Perspective of the Respondents with Experienced over 10 years

As shown in the graph of the respondents with more than ten years of experience in Figure 4, such respondents showed results similar to those of all other respondents. In particular, those with more than ten years of experience considered the 'Assignment of responsibility for DfS to the client' as relatively important $(0.237)$ because they felt that the clients lack a sense of responsibility for safety management. As those with a wealth of experience also have great knowledge of construction safety in relation to the DfS process, they recognized that the 'Development of a decision support system' (0.117) is less important compared to all other respondents.

\subsection{Discussion}

In this paper, the absolute importance and relative importance of eight DfS alternatives were examined. The analysis showed that the importance of the 'Assignment of responsibility for DfS to the client' among the eight alternatives was most important in terms of the absolute importance and relative importance. In particular, in the results of the relative importance for construction project participants, the 'Assignment of responsibility for DfS to the client' was highly ranked in terms of importance among all participants. Based on this, it is clear that the client's role is most important when implementing DfS. During the implementation of DfS, the issue on the responsibility of client is important not only in South Korea but also in other countries [17,24,28,29,42].

As mentioned earlier, if the client is involved in the entire construction process, the client will have a profound impact on the level of construction safety. If the client actively participates in construction safety management, the number of accidents at construction sites will decrease. Unlike other participants who participate in the DfS process at each stage, the client can efficiently manage the DfS process because client is involved in all processes of the DfS. Thus far, however, the client has had no legal responsibility to engage in such activities, and South Korea has had difficulty in implementing DfS. Hence, by giving clients the responsibility to manage the DfS process efficiently, South Korea will be able to implement DfS efficiently and ultimately reduce the number of accidents in the construction industry. Therefore, most important in order to improve DfS is to assign responsibility of the client. New legislation should be enacted to give responsibility to such clients in South Korea.

\section{Conclusions}

To realize safe construction projects, fatal incidents should ultimately be eliminated. To do this effectively, construction safety management should be taken into account in the design phase instead of the construction phase. Therefore, this study presented eight Design for Safety (DfS) alternatives for improving DfS in South Korea, and a questionnaire survey and fuzzy analytical hierarchy process (F-AHP) analysis were carried out to identify the priority levels of such DfS improvement alternatives. The research process that was employed here is as follows: (1) definition of the DfS improvement alternatives, (2) conduct of the questionnaire survey, and (3) calculation and analysis of the weighting factors.

First, based on previous studies related to DfS, eight DfS improvement alternatives for South Korea were presented. Second, a questionnaire survey was carried out to identify the degrees of importance of the eight DfS improvement alternatives. The 27 respondents who participated here all had links to the construction industry. They were five clients, five designers, eight contractors, four construction managers, and five researchers. Nine respondents had less than ten years of experience, and eighteen respondents had more than ten years of experience. Based on the results of the questionnaire survey, the absolute importance of the eight DfS improvement alternatives was identified. An analysis of variance was carried out for validation. Third, the F-AHP analysis was performed considering the following three criteria: (1) the overall respondents' perspective, (2) the construction project participants' perspectives, and (3) the career level. 
The results of the study are as follows. First, the results of the absolute importance of the eight DfS improvement alternatives from all respondents' perspective showed that all respondents recognized the need for the eight DfS improvement alternatives. In particular, however, the absolute importance of the alternatives was highest among the researchers, as the researchers recognized through their research that the DfS process can effectively reduce the number of construction accidents.

Second, the results of the relative importance of each of the eight DfS improvement alternatives from the perspective of all respondents showed that the perceived top priority with regard to improving DfS in South Korea was the 'Assignment of responsibility for DfS to the client' (0.196). This suggests that in South Korea, construction project clients lack a sense of responsibility during the DfS process. The least urgent improvement item was the 'Application of extended coverage' (0.089).

Third, the results of the relative importance of each of the eight DfS improvement alternatives by construction project participant revealed that there is a significant difference in the recognition of the importance of improving DfS according to the roles and positions of the construction project participants. The clients of public construction projects, who implement the DfS process, recognized the relative importance of the 'Application of extended coverage' (0.160). Meanwhile, the designers, who want to reflect design alternatives regarding risk factors in the construction design, placed relatively more importance on the 'Application of a design alternative' (0.147), while the contractors perceived the 'Development of a decision support system' (0.215), helpful during the DfS process, as a relatively important alternative. In addition, the contractors, who cannot participate in the DfS process due to the conventional project delivery method in South Korea, recognized the relative importance of the 'Development of a collaboration program' (0.117). The construction managers, who examine how well the contractor implements the DfS process, recognized the 'Involvement of the contractor in the pre-construction phase' (0.250) as relatively more important than the other DfS improvement alternatives due to the expectation that early participation of the contractor in the construction process will ensure better implementation of the DfS process in the construction phase. The researchers, who investigate the DfS process, considered the 'Assignment of responsibility for DfS to the client' as relatively more important (0.245).

Fourth, the results of the relative importance of each of the eight DfS improvement alternatives by career level confirmed that respondents with less than ten years of experience recognized all alternatives as being equally important, without variations in the relative importance levels. In addition, due to their lack of knowledge about the DfS process, they recognized the 'Development of a decision support system' (0.178) as relatively important. On the other hand, those with more than ten years of experience assigned special importance to the 'Assignment of responsibility for DfS to the client' (0.237).

The contributions of this study are as follows. First, for the first time in South Korea, a study deduced and presented the improvements that need to be made to DfS in South Korea from the perspective of construction project participants and based on the career level. Second, the preferential improvements based on the perspectives of the construction project participants and by career level were identified, and the study findings can be utilized as basic data for the establishment of detailed measures by which to improve DfS in Korea. Third, policy makers can use the results of this study to improve DfS for construction project in South Korea.

This study, however, has the following limitations. First, it was difficult to conduct a survey among experts with much knowledge of DfS because the introduction of DfS in South Korea is still in its infancy. Second, this study seeks to find DfS problems; thus, through a literature review and a questionnaire survey, eight DfS alternatives are presented. However, except for the eight DfS alternatives, other difficult to find problems may also exist. Therefore, in future work, when the DfS process will have been activated in South Korea, DfS improvements in the country based on the results of an extensive questionnaire survey involving DfS experts can be suggested. In addition, further research is needed to present action plans for the DfS improvement priorities from the perspectives of the various construction project participants based on the findings of this study. 
Author Contributions: Conceptualization, J.S. and J.J. (Jaewook Jeong); Investigation, J.S., J.J. (Jaewook Jeong) and J.J. (Jaemin Jeong); Resources, J.S., J.J. (Jaewook Jeong) and J.J. (Jaemin Jeong); Writing-original draft, J.S.; Writing-review \& editing, J.J. (Jaewook Jeong) and J.J. (Jaemin Jeong). All authors have read and agreed to the published version of the manuscript.

Funding: This work was supported by a National Research Foundation of Korea (NRF) grant funded by the South Korean government (MSIP; Ministry of Science, ICT \& Future Planning) (No. 2019R1G1A1100128)

Conflicts of Interest: The authors declare no conflict of interest.

\section{References}

1. Guo, B.H.; Yiu, T.W.; González, V.A. Predicting safety behavior in the construction industry: Development and test of an integrative model. Saf. Sci. 2016, 4, 1-11. [CrossRef]

2. Shafiq, M.T.; Afzal, M. Potential of Virtual Design Construction Technologies to Improve Job-Site Safety in Gulf Corporation Council. Sustainability 2020, 12, 3826. [CrossRef]

3. Pham, H.C.; Dao, N.N.; Cho, S.; Nguyen, P.T.; Pham-Hang, A.T. Construction Hazard Investigation Leveraging Object Anatomization on an Augmented Photoreality Platform. Appl. Sci. 2019, 9, 4477. [CrossRef]

4. Ministry of Employment and Labor (MOEL). A Report on Industrial Accidents in 2019. 2020. Available online: http://www.moel.go.kr/index.do (accessed on 1 May 2020).

5. Behm, M. Linking construction fatalities to the design for construction safety concept. Saf. Sci. 2005, 43, 589-611. [CrossRef]

6. Hallowell, M.R.; Hansen, D. Measuring and improving designer hazard recognition skill: Critical competency to enable prevention through design. Saf. Sci. 2016, 82, 254-263. [CrossRef]

7. Ahn, H.S. A study on the improvement of the safety organizations for construction projects. J. Archit. Inst. Korea 2005, 21, 137-144. Available online: http://www.dbpia.co.kr/journal/articleDetail?nodeId= NODE00634591 (accessed on 16 January 2020).

8. Atkinson, A.R.; Westall, R. The relationship between integrated design and construction and safety on construction projects. Constr. Manag. Econ. 2010, 28, 1007-1017. [CrossRef]

9. Zhou, Z.; Goh, Y.M.; Li, Q. Overview and analysis of safety management studies in the construction industry. Saf. Sci. 2015, 72, 337-350. [CrossRef]

10. Gambatese, J.A.; Behm, M.; Hinze, J.W. Viability of designing for construction worker safety. J. Constr. Eng. Manag. 2005, 131, 1029-1036. [CrossRef]

11. Health and Safety Executive (HSE). Construction (Design and Management) Regulations 2015. 2015. Available online: https://www.hse.gov.uk/construction/cdm/2015 (accessed on 2 January 2020).

12. National Institute for Occupational Safety and Health (NIOSH). The State of the National Initiative on Prevention through Design. DHHS/NIOSH Publication No. 2014-123; 2013. Available online: https: //www.cdc.gov/niosh/index.htm (accessed on 2 January 2020).

13. The Federal Register of Legislation. Work Health and Safety Act 2011. 2011. Available online: https: //www.legislation.gov.au/ (accessed on 2 January 2020).

14. Workplace Safety and Health (Council WSH COUNCIL). Workplace Safety and Health Guidelines Design for Safety. 2016. Available online: https://www.wshc.sg/ (accessed on 2 January 2020).

15. Toole, T.M.; Gambatese, J. The trajectories of prevention through design in construction. J. Saf. Res. 2008, 39, 225-230. [CrossRef] [PubMed]

16. Ogunde, A.O.; Owolabi, D.J.; Kukoyi, P.O.; Oloke, O.C. Evaluation of the Level of Compliance with Construction Design Management (CDM 2007) Regulations by clients in Nigeria. Covenant J. Res. Built Environ. 2016, 1, 42-52.

17. Ministry of Land, Infrastructure and Transport (MLIT). Design for Safety Business Manual. 2017. Available online: http://www.molit.go.kr/portal.do (accessed on 2 January 2020).

18. Ji, K.H.; Choi, B.J. A study on safety improvement of domestic construction industry subject to design for safety review. J. Korea Saf. Manag. Sci. 2017, 19, 63-76. [CrossRef]

19. Kim, S.E.; Jeong, J.M.; Jeong, J.W. Improvements of Design for Safety in Korea based on the Comparative Analysis with Other Countries. J. Korean Soc. Saf. 2019, 34, 38-49. [CrossRef] 
20. The Ministry of Government Legislation (MOLEG). Enforcement Decree of the Construction Technology Promotion Act. 2020. Available online: https://www.moleg.go.kr/ (accessed on 2 January 2020).

21. Shin, W.S.; Son, C.B. An Awareness Analysis on the Design for Safety of Construction Project and Its Improvement Measures. J. Korea Inst. Build. Constr. 2019, 19, 351-359. [CrossRef]

22. Lee, Y.; Kim, I.; Choi, J. Development of BIM-Based Risk Rating Estimation Automation and a Design-for-Safety Review System. Appl. Sci. 2020, 10, 3902. [CrossRef]

23. Kim, I.; Lee, Y.; Choi, J. BIM-based Hazard Recognition and Evaluation Methodology for Automating Construction Site Risk Assessment. Appl. Sci. 2020, 10, 2335. [CrossRef]

24. Ahn, H.S. Promotion of Client-Initiative Construction Safety and Health Management. J. Rgnl. Assoc. Archit. Inst. Korea 2006, 12, 353-360. Available online: https://www.earticle.net/Article/A132705 (accessed on 2 January 2020).

25. Langar, S.; Bhattacharjee, S.; Ghosh, S. Prevention through Design (PtD): Current State of Implementation in the Design Industry. In Proceedings of the 52nd ASC Annual International Conference, Provo, UT, USA, 13-16 April 2016.

26. Toh, Y.Z.; Goh, Y.M.; Guo, B.H. Knowledge, attitude, and practice of design for safety: Multiple stakeholders in the Singapore construction industry. J. Constr. Eng. Manag. 2016, 143, 04016131. [CrossRef]

27. Toole, T.M.; Gambatese, J.A.; Abowitz, D.A. Owners' role in facilitating prevention through design. J. Prof. Issues Eng. Educ. Pr. 2017, 143, 04016012. [CrossRef]

28. Tymvios, N.; Gambatese, J.A. Perceptions about design for construction worker safety: Viewpoints from contractors, designers, and university facility owners. J. Constr. Eng. Manag. 2016, 142, 04015078. [CrossRef]

29. Ahn, H.S. Built-in mechanisms of client-initiative construction safety management in CDM. J. Rgnl. Assoc. Archit. Inst. Korea 2011, 13, 297-304. (accessed on 16 January 2020).

30. Ahn, H.S. A Study on the Comparison of Construction Safety Management Legislations between ROK and UK. J. Rgnl. Assoc. Archit. Inst. Korea 2018, 20, 189-196. Available online: https://www.earticle.net/Article/A326139 (accessed on 12 March 2020).

31. Gangolells, M.; Casals, M.; Forcada, N.; Roca, X.; Fuertes, A. Mitigating construction safety risks using prevention through design. J. Saf. Res. 2010, 41, 107-122. [CrossRef] [PubMed]

32. Kwon, O.; Cho, J.; Jo, C. BIM Quality Assurance for DFS in Design Phase. Korean J. Comput. Des. Eng. 2013, 18, 348-358. [CrossRef]

33. Sadeghi, L.; Mathieu, L.; Tricot, N.; Al Bassit, L. Developing a safety indicator to measure the safety level during design for safety. Saf. Sci. 2015, 80, 252-263. [CrossRef]

34. Shin, J.Y. Development plan of design for safety in construction. Tunn. Undergr. Space 2017, 27, 351-356. [CrossRef]

35. Zhang, S.; Teizer, J.; Lee, J.K.; Eastman, C.M.; Venugopal, M. Building information modeling (BIM) and safety: Automatic safety checking of construction models and schedules. Autom. Constr. 2013, 29, 183-195. [CrossRef]

36. Doloi, H. Application of AHP in improving construction productivity from a management perspective. Constr. Manag. Econ. 2008, 26, 841-854. [CrossRef]

37. Raviv, G.; Shapira, A.; Fishbain, B. AHP-based analysis of the risk potential of safety incidents: Case study of cranes in the construction industry. Saf. Sci. 2017, 91, 298-309. [CrossRef]

38. Jaskowski, P.; Biruk, S.; Bucon, R. Assessing contractor selection criteria weights with fuzzy AHP method application in group decision environment. Autom. Constr. 2010, 19, 120-126. [CrossRef]

39. Frijters, A.C.; Swuste, P.H. Safety assessment in design and preparation phase. Saf. Sci. 2008, 46, $272-281$. [CrossRef]

40. Kim, J.W.; Kim, J.J. Disaster Risk Assessment by Work Unit of Construction Work for Improve the Efficiency of Design for Safety Task. J. Archit. Inst. Korea Struct. Constr. 2018, 34, 45-53. [CrossRef]

41. MacLeamy, P. Collaboration, Integrated Information, and the Project Lifecycle in Building Design and Construction and Operation. WP-1202. August 2004. Available online: https://kcuc.org/wp-content/uploads/ 2013/11/Collaboration-Integrated-Information-and-the-Project-Lifecycle.pdf (accessed on 12 March 2020).

42. Huang, X.; Hinze, J. Owner's role in construction safety. J. Constr. Eng. 2006, 132, 164-173. [CrossRef]

43. Maynard, D.D.C.; Zandonadi, R.P.; Nakano, E.Y.; Botelho, R.B.A. Sustainability Indicators in Restaurants: The Development of a Checklist. Sustainability 2020, 12, 4076. [CrossRef] 
44. George, D. SPSS for Windows Step by Step: A Simple Guide and Reference. 11.0 Update, 4th ed.; Allyn \& Bacon: Boston, MA, USA, 2003.

45. Aminbakhsh, S.; Gunduz, M.; Sonmez, R. Safety risk assessment using analytic hierarchy process (AHP) during planning and budgeting of construction projects. J. Saf. Res. 2013, 46, 99-105. [CrossRef]

46. Jeong, J.; Hong, T.; Ji, C.; Kim, J.; Lee, M.; Jeong, K. Development of an integrated energy benchmark for a multi-family housing complex using district heating. Appl. Energy 2016, 179, 1048-1061. [CrossRef]

47. Jeong, J.; Hong, T.; Ji, C.; Kim, J.; Lee, M.; Jeong, K. Development of an evaluation process for green and non-green buildings focused on energy performance of G-SEED and LEED. Build. Environ. 2016, 105, 172-184. [CrossRef]

48. Jeong, J.; Hong, T.; Ji, C.; Kim, J.; Lee, M.; Jeong, K.; Koo, C. Development of a prediction model for the cost saving potentials in implementing the building energy efficiency rating certification. Appl. Energy 2017, 189, 257-270. [CrossRef]

49. Jeong, J.; Hong, T.; Ji, C.; Kim, J.; Lee, M.; Jeong, K.; Koo, C. Improvements of the operational rating system for existing residential buildings. Appl. Energy 2017, 193, 112-124. [CrossRef]

50. Shih, H.Y.; Yao, Y.S. Indicators of Low-Carbon Management in the Leisure Industry: Research Using Examples in Taiwan and China. Sustainability 2020, 12, 4326. [CrossRef]

51. Shafique, M.; Rafiq, M. An overview of construction occupational accidents in Hong Kong: A recent trend and future perspectives. Appl. Sci. 2019, 9, 2069. [CrossRef]

52. Zimmerman, D.W. A note on preliminary tests of equality of variances. Br. J. Math. Stat. Psychol. 2004, 57, 173-181. [CrossRef] [PubMed]

53. Kokangül, A.; Polat, U.; Dağsuyu, C. A new approximation for risk assessment using the AHP and Fine Kinney methodologies. Saf. Sci. 2017, 91, 24-32. [CrossRef]

54. Muhammad, A.; Siddique, A.; Youssef, A.E.; Saleem, K.; Shahzad, B.; Akram, A.; Al-Thnian, A.B.S. A Hierarchical Model to Evaluate the Quality of Web-Based E-Learning Systems. Sustainability 2020, 12, 4071. [CrossRef]

55. Wang, G.; Liu, H.; Li, H.; Luo, X.; Liu, J. A Building Project-Based Industrialized Construction Maturity Model Involving Organizational Enablers: A Multi-Case Study in China. Sustainability 2020, 12, 4029. [CrossRef]

56. Kutlu, A.C.; Ekmekçioğlu, M. Fuzzy failure modes and effects analysis by using fuzzy TOPSIS-based fuzzy AHP. Expert. Syst. Appl. 2012, 39, 61-67. [CrossRef]

57. Lyu, H.M.; Sun, W.J.; Shen, S.L.; Zhou, A.N. Risk assessment using a new consulting process in fuzzy AHP. J. Constr. Eng. Manag. 2020, 146, 04019112. [CrossRef]

58. Phung, X.L.; Truong, H.S.; Bui, N.T. Expert System Based on Integrated Fuzzy AHP for Automatic Cutting Tool Selection. Appl. Sci. 2019, 9, 4308. [CrossRef] 